\title{
DIFFERENT MODELS USED IN AFRICA AND ASIA FOR OFF GRID ELECTRIFICATION AND THE CHALLENGES FACED
}

\author{
LALITHA MAHALINGAM \& JAIDEEP PRABHU \\ University of Cambridge, Cambridge, UK.
}

\begin{abstract}
This paper explores the different models used for rural electrification in developing countries. The unsuccessful projects and their causes of failure are analysed and some components of successful projects are also outlined. The analysis proves that there is more to just the technology aspect of the deployment and the socio economic and political factors play a major role in determining success of the programs. The two most successful models for the large scale dissemination of solar systems are this fee-for-service model and the micro-credit scheme.

Keywords: fee for service, micro credit schemes, off grid electrification models, rural electrification.
\end{abstract}

\section{INTRODUCTION}

The objective of this paper is to demonstrate the different models for rural electrification in developing countries and problems faced. According to literature reviews the two main market based models for the large scale dissemination of solar systems are this fee-for-service model and the micro-credit scheme [1,2]. These two models proved to be desirable in South Africa and different parts of south Asia.

These questions sought to be answered in this paper are

a. What are the challenges faced by rural electrification programs?

b. What are the components of successful models?

Despite challenges, countries in Latin America such as Costa Rica Brazil, Mexico, Argentina and Chile and developing Asia such as Thailand, Nepal, India Sri Lanka, Indonesia, Cambodia, Bangladesh and China have recorded success in rural electrification programs using mini-grid [3-5].

Unlike the developed world where off grid is used to boost energy security and power quality, in the developing world, off grids and mini grids concern mostly to remote rural areas to bring about power availability through increasing access to electricity [6].

A survey by United Nations Development Programme, International Energy Agency and World Bank showed that most of the African countries and Peru has the highest potential for investing in off grid electrification. Among the country ranking of 89 countries India features 38th [3].

It is necessary to explore if grid extension is a least cost option, if not then renewable off grid have to be employed [7]. Given below is a summary of the different systems and their features. 


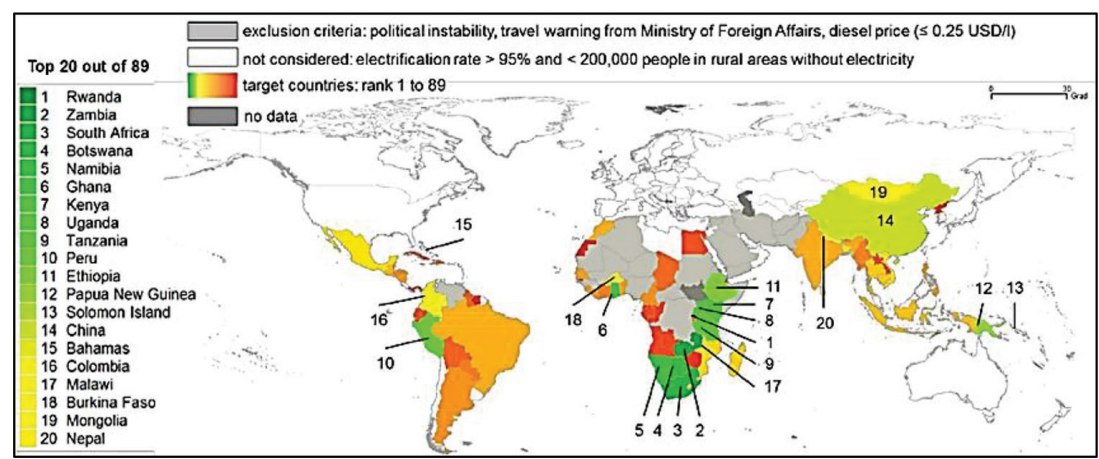

Figure 1: Ranking of market potential for off grid projects. Data are taken from UNDP, IEA, GIZ and World Bank [3].
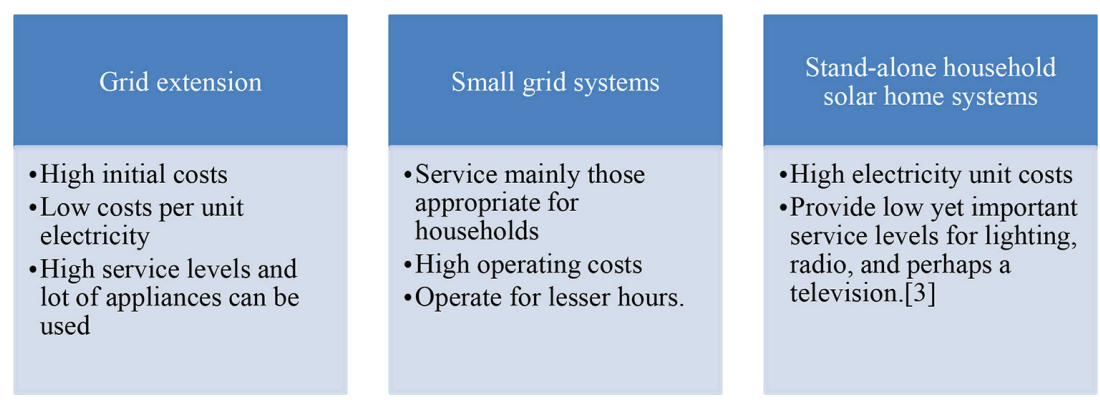

Figure 2: Different electrification systems and features [7].

\section{DISCUSSION}

2.1 The two successful models used for off grid electrification

\section{Micro credit scheme}

The advantage of microcredit scheme is using an already existing micro finance institution, which have a good customer knowledge at the locality [2]. In case of micro credit scheme, enterprises take charge of the maintenance, but the financial support is done by a separate institution. Some Asian countries have achieved large-scale dissemination of solar home systems in the range of several hundred thousand systems funded by microcredit schemes [2].

Household systems - In Bangladesh, a quite successful off grid rural electrification program is administered by the Infrastructure Development Company Limited (IDCOL), a public financial institution, microfinance organizations, nongovernmental organizations, municipalities, and private-sector institutions - both credit and grants with which to purchase solar home systems [6].

Among the off grid approaches are the decentralized models. Small grid systems such as in Nepal and Sri Lanka community grid systems rely on local micro-hydropower. In Sri Lanka, a development bank with a specialized unit for off grid electricity has provided 
financing to microfinance institutions, leasing companies, and nongovernmental organizations to support solar home systems and community micro-hydropower systems [8].

\section{Fee-for-service concessions}

In case of fee-for-service scheme, Long term concession is given for small scale companies and loan can be got from government. So there is low cost for installation and a fee is charged of customers for delivery of electricity [2].

The scheme was successfully implemented in Zambia. In the eastern province of Zambia, three companies for solar energy services have been operating for more than 2 years, with 400 clients paying for the use of solar photovoltaic (PV) installations.

The customers pay a higher price for electricity with the off grid scheme compared to that spent on kerosene and candles. But the benefit cited overweighs the extra cost paid.

The key element for success in providing energy services in this case is the proximity to clients. Service technicians were able to reach the clients on foot or bicycle. It was also important for getting payments on time and keep defaulting at a minimum [8].

\subsection{Problems faced with off grid electrification programs}

Some of the problems face with off grid electrification are up front cost of installing the system, long term maintenance, institutional issues and the cost of renewing batteries. Sometimes Capital subsidies are disrupted from government which makes it unattractive for companies to think of long term investment. There are also problems with day-to-day organisation and logistics. For example in case of the NuRa (Nuon-RAPS ) corporation in South Africa it was given 10 days to repair breakdown and 30 days to attend to any other complaints. The entire process of resolving a failure took several weeks as the customer needs to signal his problem to the nearest energy store, then they log the failure which is sent electronically to the headquarters, technicians have then to be sent from NuRa's headquarters. Even with the help of GPS, to find the right path to get access to a house can be tricky and time-consuming: in 1 day, technicians may be able to visit only $4-5$ houses [2].
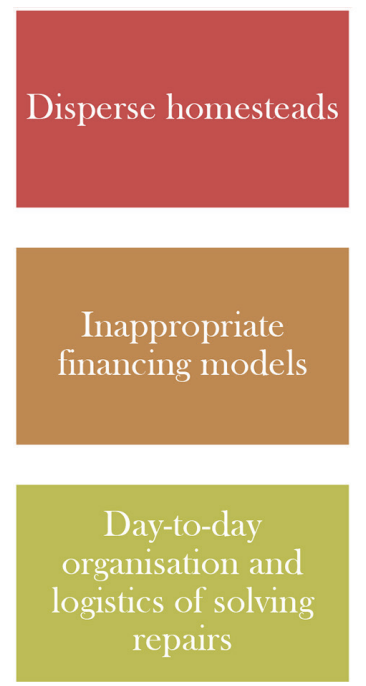
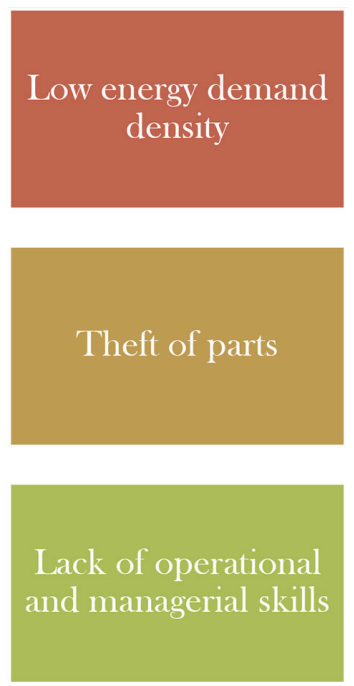
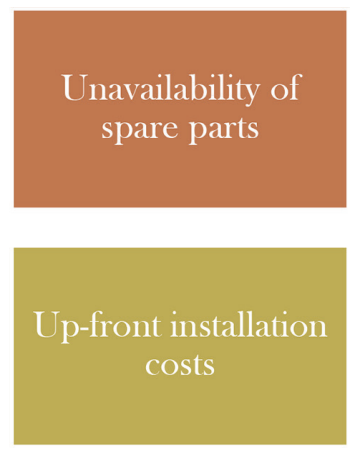

Lack of technical knowledge needed to run and maintain the systems

Figure 3: Issues deterring sustenance of renewable electrification projects [4]. 
Table 1: List of projects that failed and their reasons.

\begin{tabular}{|c|c|}
\hline Projects & Reason for failure \\
\hline $\begin{array}{l}\text { Zimbabwe a GEF- UNDP funded off-grid } \\
\text { electrification program }\end{array}$ & $\begin{array}{l}\text { Did not survive after the project came to an } \\
\text { end. Lack of follow up. }\end{array}$ \\
\hline $\begin{array}{l}\text { Hydro base mini-grid systems implemented } \\
\text { in Lesotho }\end{array}$ & $\begin{array}{l}\text { Maintenance issues and high production } \\
\text { cost }\end{array}$ \\
\hline $\begin{array}{l}\text { Hybrid solar-biogas mini-grid project at } \\
\text { Sekhutlane village in Botswana }\end{array}$ & Technical and managerial challenges \\
\hline $\begin{array}{l}\text { Lucingweni pilot hybrid mini-grid project } \\
\text { in South Africa }\end{array}$ & $\begin{array}{l}\text { Inadequate feasibility study, high electric- } \\
\text { ity production cost, insufficient community } \\
\text { engagement, and lack of expertise required } \\
\text { to run and manage the plant }\end{array}$ \\
\hline $\begin{array}{l}\text { Pilot for establishment of low carbon hybrid } \\
\text { mini-grid in a country like Nigeria }\end{array}$ & $\begin{array}{l}\text { Policy inconsistency and lack of political } \\
\text { will has hindered the off take of projects }\end{array}$ \\
\hline
\end{tabular}

Some clients were dissatisfied with the limit of wattage provided, which was only $50 \mathrm{~W}$ peak panel. It was also a hassle to deal with paying while system is not functioning. The issue of theft is also to be addressed where parts of systems are stolen in owner's absence [2].

2.3 Successful projects and their components of success

\section{Tsumkwe hybrid solar-diesel mini-grid}

A project in Namibia was considered one of the successful projects of off grid electrification. The project has been in operation since its commissioning in 2012 and is relatively successful. The components of success are given below.

Ownership: Financial management scheme adopted by OTRC, who own and maintain the system

Revenue collection method: prepaid metering of the electricity supply to users. escrow account to ensure that money collected is reinvested in the system for maintenance, replacement and upgrade

Government support: government in the form of subsidies to cover the shortfall in revenue as well as providing skilled operators that have the capability to maintain the system [7].

\section{IDCOL Bangladesh}

In 2003, state-owned Infrastructure Development Company Limited (IDCOL) began a program to scale SHS. Backed by World Bank, Global Environment Facility, US Agency for International Development, UK Department for International Development (DFID) and others. IDCOL's efforts resulted in more than a decade of exponential growth for SHS.

Lesson learnt about reducing subsidies from SHS Program in Bangladesh are that Subsidies are unlikely to lead to sustainable markets unless they explicitly create the conditions, whereby they are no longer needed (i.e. smart subsidies) and that subsidies can be used effectively to build up initial market volume, local expertise, user awareness, appropriate technology adaptation, quality standards and entrepreneurial activities. Continuing subsidies may always be needed for poorer segments of the population. 
Table 2: Challenges IDCOL Solar Program taken from Ref. [9].

\begin{tabular}{ll}
\hline Problems & Solutions \\
\hline Lack of capacity & Equipped to develop private sector, i.e MFI, NGOs \\
& Grass-root level are working as the executing agencies \\
& Adequate financial supports provided by donor agencies \\
Cack of tailored financing & $\begin{array}{l}\text { Capital Buy-down Grant channelled to reduce system price } \\
\text { Institutional development Grant and Grant B do not exists. }\end{array}$ \\
package & Capital Buy-down Grant reduces system price; \\
High initial cost of solar & Systems are also sold on credit to households to ensure \\
equipment & affordability; \\
Lack of business model & A social enterprise model is used for implementation \\
& Presence of multiple POs in the program \\
& A phase-reduction nature of grant is used \\
\hline
\end{tabular}

\section{CONCLUSION}

Analysis of the projects prove that the technical aspect of the of grid electricity deployment is only one part of the complete picture and there are various elements which determine the success factor of a project. Some essential elements required for success of projects are commitment from government, grass root level involvement of NGOs and companies, adequate financing models, subsidies which explicitly create the conditions whereby they are no longer needed, logistical issues and good revenue collection methods. Some factors that deter sustenance of off grid projects are dispersed homesteads, low energy demand density, unavailability of spare parts, inappropriate financing models, theft of parts, upfront installation costs, day-to-day organisation and logistics of solving repairs, Lack of operational and managerial skills and lack of technical knowledge needed to run and maintain the systems.

Among the various models, fee for service concession and micro credit schemes have proved to be most successful.

\section{REFERENCES}

[1] www.revistavirtualpro.com, A review of international literature of ESCOs and fee-forservice approaches to rural electrification, solar home systems [Online]. available at: http://www.revistavirtualpro.com/biblioteca. (Accessed 18 February 2017).

[2] Lemaire, X., Off-grid electrification with solar home systems: the experience of a feefor-service concession in South Africa. Energy for Sustainable Development, 15(3), pp. 277-283, 2011. https://doi.org/10.1016/j.esd.2011.07.005

[3] Gerlach, A.K., Gaudchau, E., Cader, C., Wasgindt, V. \& Breyer, C., Comprehensive country ranking for renewable energy based mini-grids providing rural off-grid electrification, 2013.

[4] Banerjee, S.G., Singh, A. \& Samad, H., Power and people: the benefits of renewable energy in Nepal, A world bank study, 2011.

[5] Carvallo, J. \& Carvallo, J., Sustainable development of renewable energy mini-grids for energy access: a framework for policy design, 2013.

https://doi.org/10.2172/1171612 
[6] Azimoh, C.L., Klintenberg, P., Mbohwa, C. \& Wallin, F., Replicability and scalability of mini-grid solution to rural electrification programs in sub-Saharan Africa. Renewable Energy, 106, pp. 222-231, 2017.

https://doi.org/10.1016/j.renene.2017.01.017

[7] Barnes, D.F., Effective solutions for rural electrification in developing countries: lessons from successful programs. Current Opinion Environmental Sustainability, 3(4), pp. 260-264, 2011. https://doi.org/10.1016/j.cosust.2011.06.001

[8] Ellegård, A., Arvidson, A., Nordström, M., Kalumiana, O.S. \& Mwanza, C., Rural people pay for solar: experiences from the Zambia PV-ESCO project. Renewable Energy, 29(8), pp. 1251-1263, 2004.

https://doi.org/10.1016/j.renene.2003.11.019

[9] Sharif, I. \& Mithila, M., Rural electrification using PV: the success story of Bangladesh. Energy Procedia, 33, pp. 343-354, 2013.

https://doi.org/10.1016/j.egypro.2013.05.075 